\title{
Duelos y mitos en la memoria sísmica chilena. El reemplazo del rito de pérdida por la pornografía de la muerte
}

\author{
Sonia Montecino ${ }^{1}$
}

\begin{abstract}
El símbolo es un pivote social muy importante, sobre el que se apoyan otros procesos de simbolización. La subjetivación de una pérdida consiste en ir localizando para sí y luego al mismo tiempo públicamente, ese trozo de síque se llevó el muerto con su muerte. Se trata de una pérdida suplementaria: el muerto más lo que se perdió con él (Araceli Colin, 97)².
\end{abstract}

La noche del 27 de febrero quienes habitamos entre Temuco y Valparaíso vivimos una situación límite; pensamos -sobre todo en los sitios donde la intensidad del sismo fue más fuerte que lo usualen nuestro fin, vivenciamos, de un modo $u$ otro, nuestra muerte y algunos/as nos entregamos a eso que el historiador Rolando Mellafe denominó el "acontecer infausto de Chile". Dependiendo de los "años de terremoto en el cuerpo" quien más y quien menos sufrió la angustia de la pérdida, de la propia, de los suyos y de las materialidades que lo rodean. Arrojados/as a la pura contingencia, el terremoto nos democratizó por unos minutos, por un lapso la muerte asoló a ricos y pobres, por instantes el tejido social entero se rasgó porque la muerte -una en particular o cualquiera en general-desorganizó lo que la trama de la cultura hila incansablemente.

Sin rito -entendido como solución a una contradicción indisoluble- es muy difícil elaborar personal y socialmente el duelo que sigue a toda pérdida, eso lo sabían y saben los mapuche. El mito del Kai Kai y Ten Ten se ha narrado por siglos en las tierras del sur de Chile: de modo esquemático el relato alude a la lucha entre Kai Kai, la fuerza de los espíritus del mar y de las aguas y Ten Ten las de la tierra y las montañas, simbolizadas ambas en dos culebras, una que anega y ahoga y otra que salva a las personas elevando la tierra. La aniquilación de casi todos los mapuche fue ocasionada por esa contienda telúrica y líquida y, quienes sobrevivieron encaramados a los cerros, tuvieron que propiciar a esos espíritus por 
medio de un ritual sacrificial. Sólo así se calmaron las inundaciones y pudo devenir una segunda generación que repobló la tierra. La memoria de terremotos y maremotos se ha ido transmitiendo a través de Kai Kai y Ten Ten y los ritos asociados han ido conjurando, pero al mismo tiempo, recordando esas pérdidas en la repetición del lenguaje de los cuerpos orantes y de las ofrendas sacrificiales.

Nada parecido tuvimos los/as ciudadanos urbanos y modernos (es decir individualizados en la soledad de nuestras opciones) del Chile afectado, ni rituales colectivos católicos, ni mapuches, ni siquiera ceremonias new age; sólo la pornografía de la muerte a través de la televisión. Ese fue el espacio que sustituyó, los primeros días del "acontecer infausto", a cualquier discurso oficial-estatal, a cualquier relato religioso, a cualquiera representación que mitigara el traspaso de los límites. Sin un ritual social y público que ayudara a frenar el desorden simbólico que trajeron consigo las pérdidas, la pantalla y la mercadotecnia se apoderaron del lenguaje del duelo convirtiéndolo en un reality show más, banalizando la muerte (precisamente porque ya no es una particular) y reproduciendo la necrofilia que los canales saben muy bien alimenta el rating ("es lo que pide la gente"): eternas repeticiones de un saqueo, como una pesadilla de la cual no se puede despertar; elogio al "flyte" que hemos visto por años convertido en el héroe de los medios de comunicación. Al son de las reiteradas imágenes pornográficas, se construían ante nuestros ojos los/as damnificados/as (ellos/as y nosotros/as) como entes transicionales, ni vivos ni muertos, porque lo habían perdido todo y ningún rito de pasaje los/as (nos) hacía transitar de un estado de carencia a uno de plenitud humana. Tardíamente se decretó un duelo nacional cuyo corolario ritual fue el superficial espectáculo de la beneficencia mediática: la Teletón con toda su carga de expiación y lavado de conciencia. El "don" dentro de una economía de mercado tiene una expresión empresarial que anula cualquier reciprocidad y por tanto cualquier equilibrio entre el donante y el receptor.

Si los mitos sirven para pensar, los terremotos y maremotos también, sobre todo porque los últimos, con su mensaje de muerte y desolación, destejen las armazones sociales. En Chile han quedado al descubierto múltiples fisuras y se han desleído muchos maquillajes, la televisión nos ha mostrado cadáveres a punto de 
corromperse que representan otra descomposición: la del tejido social remecido por la furia de Kai Kai y Ten Ten. Ante esto no ha habido verdadera respuesta colectiva sino pura levedad pornográfica, dejando entre paréntesis la urgente necesidad de simbolizar las diversas muertes que han sobrevenido y que -como dice Colin- podrían permitirnos a los deudos reconocer no sólo que perdimos a un ser o a una cosa sino lo que perdimos con ellos.

Paralela a la lucha de las dos culebras míticas, otra situación ha quedado sin ceremonias de duelo: la pérdida del poder gubernamental de la Concertación. Quiebres desde la naturaleza y quiebres políticos anegan, el alma de un buen número de

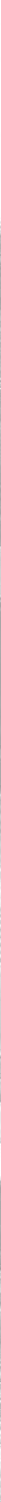


chilenos/as. Es este, entonces, un buen momento para que el acto de pensar movilice la memoria, para ejecutar esos ritos que Durkheim denominó "piaculares" y que se realizan en medio de la tristeza y la inquietud, pero que suturan simbólicamente las catástrofes. Entre los escombros de la vieja cultura chilena se encuentran, sin duda, fórmulas a las que recurrir y entre las ruinas de la nueva, algunas hebras para tejer significaciones que unan lo "fracturado estructuralmente". Tal vez así la orfandad simbólica a la que nos hemos visto arrojados mute en rituales que evoquen genealogías profundas y duraderas y no sólo la conformidad "resiliente" de la figura del chileno/a como eterno/a damnificado/a, como sempiterno/a carenciado/a.

Nota

1. Académica de la Facultad de Ciencias Sociales de la Universidad de Chile. that

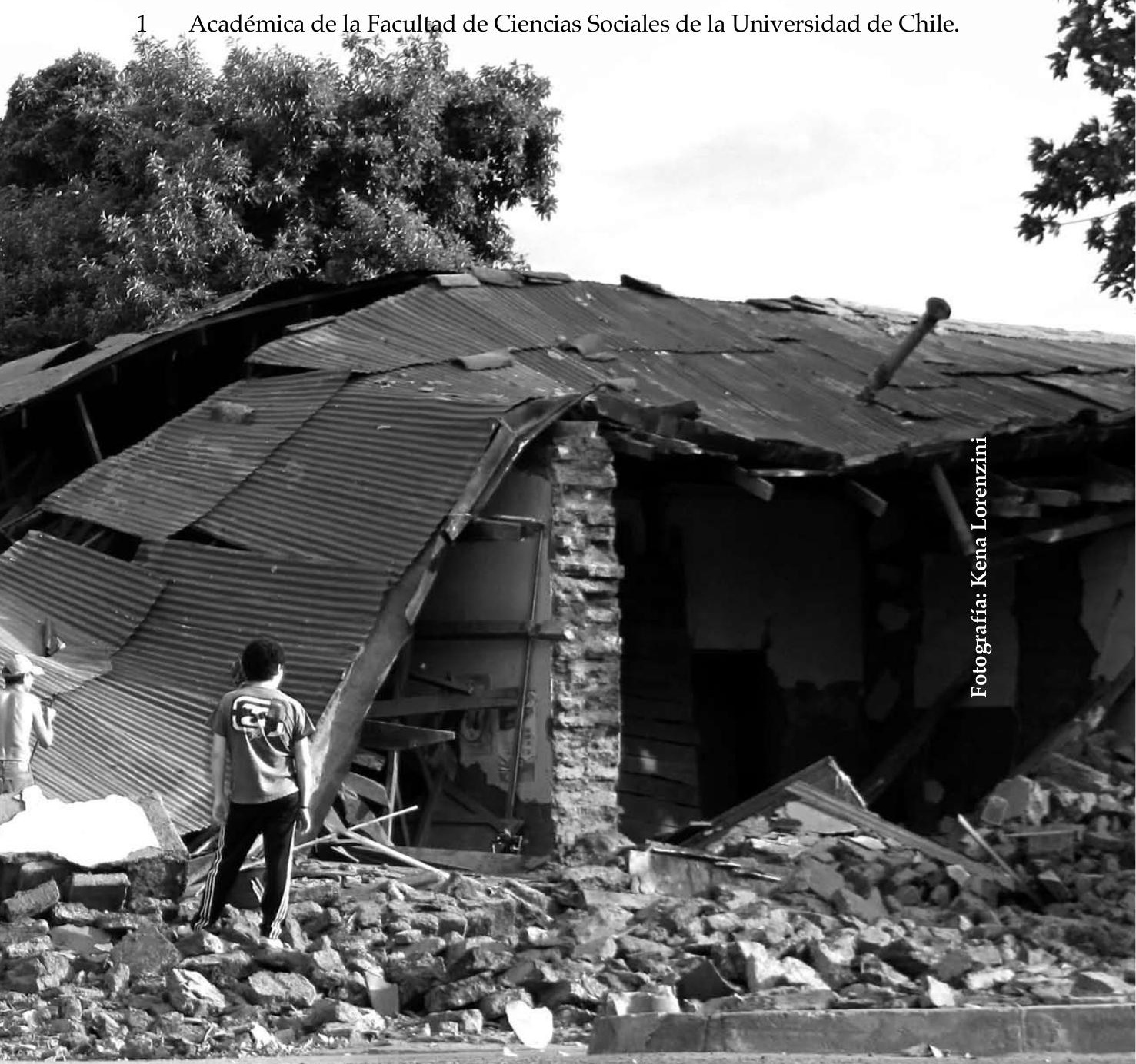

